\title{
The Feasibility of Staple Food Business and Its Implication on Regional Food Supply Chain Development
}

\author{
Sutrisno* \\ Faculty of Economic, Bojonegoro University, Bojonegoro \\ (Received April 15, 2019; Accepted May 14, 2019; Published June 20, 2019)
}

\begin{abstract}
The purpose of this research is to find out the investment feasibility of developing staple food businesses in the rural area of Bojonegoro regency, to review the financial aspects and to calculate the investment feasibility. This research used four types of analysis namely trend analysis, aspects of the investment, the investment feasibility and sensitivity. The results of the research show that there was an increase in the economic growth of $26.50 \%$ per year during 2016-2019, IRR $37.2 \%$, positive NPV, the payback period was fewer than 5 years. The sensitivity analysis shows that the possibilities of an increase in operational costs of $2.0 \%$ produced NPV 34.7 million rupiahs and the IRR $36.97 \%$, an increase such costs of $4.0 \%$ produced NPV 33.9 million rupiahs and the IRR $36.62 \%$. Meanwhile, the possibilities of a decrease in income of 2 and 4.0\% find NPV 32.4 million rupiahs and the IRR 35.99\%; and NPV value was 29,3 million rupiahs and the IRR $34.59 \%$ respectively. The results indicate that the staple food business in Bojonegoro regency was considered feasible. Furthermore, this research has implications for regional food chain development in term of the stability of domestic food production, stabilization of food prices, regulation of space infrastructure improvements and business climate of investment.
\end{abstract}

Keywords: feasibility, business, food store, staple food, supply chain

JEL Classification: D19, J54, Q12

\section{INTRODUCTION}

The policy of providing food needs has a broad perspective. Macroeconomic policies focus on price stabilization, poverty alleviation, trade between regions or countries, tariffs, subsidies or taxes. However, this policy needs to be strengthened by the microeconomic policy. The focus of microeconomic policies includes technology, production assets, marketing ,chain and distribution, and household access to markets (Barrett, 2008).

The microeconomic policy of providing food requires a huge energy boost. All public resources, institutions and public goods are prepared to build the right prices to provide incentives for production and consumption activities. This requires

\footnotetext{
* Corresponding author email: nurhidayathafid22@gmail.com, ISSN 2615-6075 online; ISSN 2615-6946 print @UWG Press, 2019

OJS http://publishing-widyagama.ac.id/ejournalv2/index.php/jsed/
}

coordination and participation of all parties to control obstacles and constraints faced by households in order to have access to food (Barrett, 2008). This becomes urgent when a region has structural barriers, poor population conditions, and transportation barriers. This condition results in low food availability, as well as high food prices, making it unaffordable for poor households (Zakari, Ying, \& Song, 2014).

Institutional constraints, infrastructure or public goods services in developing countries, are increasingly suffered when price fluctuations occur due to crop harvest failures, global impacts of climate change, or domestic and international price disparities. This requires various government interventions in order to control supply and demand, through market intervention, social programs, food assistance, production factor subsidies, including financial assistance programs (Zakari et al., 2014).

Food access by the population should be developed through various programs by the 
government. Food commodities or basic material needs have high political sensitivity. Therefore, the government should present and be ready to use the whole resources and institutions, secure the needs and availability of food from the upstream (production factors), on-farm (production technology) to downstream (post-harvest, distribution marketing) aspects (Renting, Marsden, \& Banks, 2003).

Indonesia's vast geographical conditions with heavy terrain have significant implications in the supply and needs of food. This requires a strong distribution system. The concept of food distribution is the delivery of the flow of food commodities from producers to consumers or businesses that include the activities of the flow of goods and services to consumers. The food transfer process relies on the role of food distribution businesses, including importers, distributors, and traders (Badan Ketahanan Pangan, 2016).

The role of the distribution of staple goods by traders is very important to meet the food needs of the community. Furthermore, this can support food security programs, which include (1) food availability; (2) accessibility to food; and (3) food price stability (Lantarsih, Widodo, Darwanto, Lestari, \& Paramita, 2017). The certainty in fulfilling food needs is a priority of the central and regional governments, as the main component of the main capital of national development. The staple food is a source of household consumption economic activities, as well as raw materials for small-scale industrial food to large industries.

Based on the Presidential Regulation No 71 of 2015 concerning determination and storage of basic and important goods, staple foods include rice, corn, soybeans, sugar, cooking oil, shallots, frozen meat and fresh meat, chicken and broiler eggs.

The efforts to increase and ensure food distribution are highly important to be studied. The role of staple food traders, especially in rural areas is very important for the implementation of food security programs, and their support for the economy of households or industries in rural areas. The more the number of traders, the better it is to provide these staples especially following the distribution of the population in rural areas.
Therefore, being a question is the extent to which the business feasibility of providing these staples.

The indicators that can encourage the development of business for daily necessities in the countryside are there is a lack of development of outside investors; the form of shop business is still family; there are still a lot of low income families; the village in question still has sufficient potential production. This shows that the existence of the shop business in the daily needs of the community is important in sustaining the economic life of households in rural areas. Based on the description above, the existing shop business needs to be developed.

The staple food store is one part of small and medium businesses that need to be developed and utilized optimally. For businesses development in Indonesia, the role of families in rural areas cannot be ignored. Instead, they should be fostered and supported by the Government through people's business credit policies specifically in this sector. The aim is directed at increasing the income and welfare of rural communities, providing employment and business opportunities, increasing the role of community institutions, conserving and utilizing resources.

One of the efforts that can be made by the community to earn an income is to do the community's food store as well as the existing store development. The government policy in this sector regarding business development in an effort need to be developed especially in the countryside, but due to capital constraints are an inhibiting factor for business expansion. The capital is a factor that can determine the success of rural economic development.

The main material of this feasibility study is investment, which according to Helfert (2001), investment is a commitment of funds with the aim of obtaining more economic returns over a period of time, which is usually in the form of periodic cash flow and or final value.

The calculation of economic feasibility is an important part of planning a business. It aims to ensure that the business runs efficiently, guides business decision making and produces business implications for interested parties. Thus, investment capital planted is in accordance with needs and 
efficient and produces the expected return (Vijayanti \& Yasa, 2016).

According to Soeharto (2001) the feasibility study should be able to present quantitative results about the benefits to be obtained compared to the resources needed. With quantitative presentation, decision making can be taken with certainty. According to (George \& Jones, 2005), in making an investment decision there are two criteria that must be considered, those are return and risk. Investment decisions are decisions that are related to the use of corporate capital with the aim of maximizing the rate of return.

Investment can have implications in business management or the support of other parties so that it runs conducively and efficiently. Government policy places food as a strategic thing, allowing interventions to ensure adequate, affordable and stable food needs. Interventions aim at facilitating smallholder organization, at reducing the costs of inter-market commerce, and, perhaps especially, at improving poorer households' access to improved technologies and productive assets are central to stimulating smallholder market participation and escape from semi-subsistence poverty traps (Barrett, 2008).

The research aims to analyze the trends of transactions and the economic feasibility of staple food traders in rural areas of Bojonegoro regency, and their implications for the provision of needs and distribution food in the region.

\section{RESEARCH METHOD}

This study was conducted in rural areas in Bojonegoro Regency, which included ten district areas of Sukosewu, Gondang, Kedungadem, Sugihwaras, Temayang, Bubulan, Sekar, Ngambon, Malo, and Trucuk. This study used a random sampling method, with selecting three staple food sellers in each village in those district areas. The number of staple food seller was totally thirty people. The store sells at least the commodities i.e. rice, cooking oil and eggs of the nine of staple food, as Presidential Regulation No 71 of 2015 includes rice, corn, soybeans, sugar, cooking oil, shallots, frozen and fresh meat, chicken and broiler eggs.

This study explored the primary data from the store, in term of expenditure, cost, sales, revenue, and investment during the 2014-2018 periods. Such variable data obtained using the form of interviews with shopkeepers. Interviews were carried out by asking questions concerning the nine staple food stores. Observation was worked to directly identify staple food store in the rural areas. Secondary data of this study were obtained from the village official, and relevant institution in term of interest rate or macroeconomic data.

Investment feasibility analysis used the investment criteria as the basis for receiving/rejecting or sequencing a project, consisting of net present value (NPV) internal rate of return (IRR), benefit-cost ratio ( $B / C$ Ratio) payback period and sensitivity analysis (Helfert, 2001). The sensitivity analysis is intended to assess the feasibility of an investment based on investment criteria if there are changes in the increase in operating costs or a decrease in benefits or revenues.

\section{RESULT AND DISCUSSION}

\section{Trend or Estimated Transaction}

The development of the transaction of food store during 2014-2018 shows an increase in transactions (Table 1). Based on the time series data, trend analysis was calculated using the least square method with the formula of linear regression.

Table 1. The Average of Transaction of Food Stores 2014-2018

\begin{tabular}{ccc}
\hline No & Year & Transaction $(Y)$ \\
\hline & & Millions rupiah \\
1 & 2014 & 145.0 \\
2 & 2015 & 192.0 \\
3 & 2016 & 218.5 \\
4 & 2017 & 268.0 \\
5 & 2018 & 367.5 \\
& Total & 1191.0 \\
\hline
\end{tabular}

Based on the results of the calculation of the store transaction trend in the table above then it was put into a formula, the results can be seen in the following description:

$$
\begin{aligned}
& a=1191 / 5=238.2 \\
& b=521 / 10=52.1 \\
& Y=238.2+52.1 X
\end{aligned}
$$


Based on Table 1, by making 2016 the basis for calculating the trend it can be seen that there is an increase in the average development of the food store transactions by 52.1 per year or in terms of percentage growth it can be seen that the average is $26.50 \%$. Estimates of the development of staple food store transactions in the next five years are presented in Table 2 as follows:

Table 2. Estimated of Transaction Food Stores, 20192023

\begin{tabular}{ccccc}
\hline Year & $\mathrm{X}$ & \multicolumn{2}{c}{ Amount of Transaction } \\
\hline \multirow{2}{*}{2019} & 3 & $238.2+\left(52.1^{*} 3\right)=$ & million rupiahs \\
2020 & 4 & $238.2+\left(52.1^{*} 4\right)=$ & 394.5 \\
2021 & 5 & $238.2+\left(52.1^{*} 5\right)=$ & 498.6 \\
2022 & 6 & $238.2+\left(52.1^{*} 6\right)=$ & 550.8 \\
2023 & 7 & $238.2+\left(52.1^{*} 7\right)=$ & 602.9 \\
& Total & & 2492.5 \\
\hline \multicolumn{4}{c}{} \\
\hline
\end{tabular}

\section{Investment Feasibility Analysis}

This analysis aims to prove the feasibility of an activity or project, in this case related to the feasibility study of investment in staple food stores in the research area. The data used in this analysis includes the results of field studies which include the flow of benefits to be obtained and costs that is be used in investing in the business of developing staple food stores.

\section{a. Net Present Value (NPV)}

Net Present Value is the difference in revenue and expenditure flows over the life of the project which is calculated using a discount factor. Calculation of NPV of the food store is presented in Table 3. The criteria for using NPV in an investment feasibility study are if the total NPV is equal to or smaller than 0 (NPV $\leq 0)$ then the investment to be made on a project is not feasible or unprofitable, which means that the investment plan is rejected. Conversely if the NPV is greater from 0 (NPV > 0), the investment in business development to be carried out is feasible to work on or profitable.

Based on Table 3, it can be seen that the calculation results of NPV $=35.5$ million rupiahs. It means that NPV is positive during that period so it can be concluded that the investment in the development of staple food stores in rural areas of Bojonegoro regency is feasible.

\section{b. Benefit Cost $(\mathrm{B} / \mathrm{C})$ Ratio}

Benefit Cost $(B / C)$ Ratio is the result of a comparison of gross benefit flows and costs calculated now. If $B / C$ Ratio $<1$, the investment plan in a project is not feasible and vice versa if $B / C$ Ratio $>1$, the investment plan in a project is considered feasible. From the results of the calculation of $\mathrm{B} / \mathrm{C}$ ratio of the business of staple food stores (Table 3) in the rural area of Bojonegoro District obtained the value of $B / C$ Ratio of 3.77. Therefore because of $B / C$ Ratio $>1$, it can be said that investment in the business of food store in rural Bojonegoro regency is feasible.

Table 3. The Calculation of Net Present Value (NPV)

\begin{tabular}{cccccc}
\hline No & $\begin{array}{c}\text { Gross } \\
\text { Benefit }\end{array}$ & Cost & $\begin{array}{c}\text { Net } \\
\text { benefit }\end{array}$ & $\begin{array}{c}\mathrm{df} \\
(16 \%)\end{array}$ & NPV \\
\hline & ------ & million rupiahs ------- & & -79.000 \\
0 & - & - & - & 1 & - \\
1 & 48.00 & 12.72 & 35.28 & 0.862 & 30.411 \\
2 & 48.00 & 12.72 & 35.28 & 0.743 & 26.213 \\
3 & 48.00 & 12.72 & 35.28 & 0.614 & 21.662 \\
4 & 48.00 & 12.72 & 35.28 & 0.552 & 19.475 \\
5 & 48.00 & 12.72 & 35.28 & 0.476 & 16.793 \\
\multicolumn{7}{c}{ Total NPV (df 16\%) } \\
\hline \multicolumn{7}{c}{} \\
\hline
\end{tabular}

\section{Internal Rate of Return (IRR)}

Internal Rate of Return (IRR) is a way to calculate the amount of the net average return (Return on Investment) that can be generated by the project each year during the economic life of the project. The criteria for using the IRR model in an investment feasibility study are if the percentage in the IRR $>0$ of the prevailing interest rate or Opportunity Cost of Capital (OCC) is $16 \%$ (based on the general interest rate at the time this research was conducted) and an investment is considered feasible to run. Calculation of IRR of the store is presented in Table 4.

Table 4. The Calculation of Internal Rate of Return (IRR)

\begin{tabular}{lcc}
\hline IRR & df 16\% & df 45\% \\
\hline Initial invesment & $(79.000)$ & $(79.000)$ \\
Inflow cash for year 1 & 30.411 & 24.343 \\
Inflow cash for year 2 & 26.213 & 16.793 \\
Inflow cash for year 3 & 21.662 & 11.572 \\
Inflow cash for year 4 & 19.475 & 7.973 \\
Inflow cash for year 5 & 16.793 & 5.504 \\
& 114.554 & $(66.185)$ \\
IRR = & $16 \%+21.3 \%=37.30 \%$ \\
\hline
\end{tabular}

From the results of the above calculations (Table 4), the IRR value is $37.30 \%$, that is because 
of the IRR $>\operatorname{OCC}(37.30 \%>16 \%)$. It can be stated that the investment in the business of food store in the Bojonegoro rural area is feasible to do.

\section{d. Pay Back Period}

This Pay Back Period (PBP) method is an investment criterion to find out how long all investment costs have been spent to return. If the investment plan in a Pay Back Period value project $<$ the age of the project, it means that the investment activities for developing the staple foodstuff business in the Bojonegoro Rural area are feasible. This feasibility study Pay Back Period calculation shows its value for 1 year 8 months and the Pay Back Period $<5$ years can be stated that the development of staple food businesses in the rural areas of Bojonegoro regency is feasible.

Judging from the analysis using investment criteria, namely Net Present Value, Internal Rate of Return, Benefit Cost $(B / C)$ Ratio and Pay Back Period shows that a positive value can be concluded that the investment of staple food business development in rural areas of Bojonegoro regency is economically profitable so that the investment is feasible.

\section{e. Sensitivity Analysis}

Sensitivity analysis is intended to assess feasibility based on investment criteria if there are changes in the increase in operating costs or a decrease in benefits or revenues. Return analysis is due to various possible changes, called sensitivity analyzes. In the sensitivity analysis, every possible change must be tried, which means a re-analysis is held so that more than one data is presented. Sensitivity analysis is needed because in a project analysis based on projections that contain many uncertainties about what will happen in the future due to internal and external factors. To simplify the calculation, each change is added or subtracted by the benefit or cost flow with changes in a certain percentage.

To analyze the increase in costs or benefits in sensitivity analysis, the researcher has assumed that several scenarios of operational costs increase up to $2.0 \%$ and $4.0 \%$; and income has decreased by $2.0 \%$ and $4.0 \%$. The results of the sensitivity analysis can be presented in Table 5 .
Based on the calculation of the possibility of changes in changes that can occur in the future, it appears that the results of the investment calculation of the business of staple food stores in the Bojonegoro rural area are feasible to be carried out in conditions where although operational costs increase $2.0-4.0 \%$ and if the income decreases by 2.0-4.0\%.

Table 5. The Calculation of Sensitivity Analysis

\begin{tabular}{llcc}
\hline No Recapitulation & IRR & NPV \\
\hline & & $\%$ & million rp \\
1 & Base Cost & 37.30 & 35.554 \\
2 & Case I: O\&M cost increase 2\% & 36.97 & 34.728 \\
3 & Case II: O\&M cost increase 4\% & 36.62 & 33.902 \\
4 & Case III: revenue decrease 2\% & 35.99 & 32.437 \\
5 & Case IV: revenue decrease 4\% & 34.59 & 29.320 \\
\hline
\end{tabular}

Based on the table above it is known that, if in the future there is a possibility of an increase in operational costs of $2.0 \%$, the NPV value is 34.7 million rupiahs and the IRR value is $36.97 \%$. If in the future there is a possibility of an increase in operational costs of $4.0 \%$, the NPV value is 33.9 million rupiahs and the IRR value is $36.62 \%$. Based on the table above it is known that, if in the future there is a possibility of a decrease in income of $2.0 \%$, the NPV value is 32.4 million rupiahs and the IRR value is $35.99 \%$. if in the future there is a possibility of a $4.0 \%$ decrease in income, the NPV value is 29.3 million rupiahs and the IRR value is $34.59 \%$.

Based on the calculation of the possibility of changes in changes that can occur in the future, it appears that the results of the investment calculation of the business of staple food stores in the Bojonegoro rural area are feasible to be carried out in conditions where although operational costs increase $2.0-4.0 \%$ and if income decreases by 2.0 $4.0 \%$.

In general, the results of this study indicate that the staple food business is proved to be feasible. This kind of business is included in the SME (small and medium enterprise) category. The existence of SMEs, especially in rural areas, is very important to build and strengthen economic distribution networks, mobilize workers, and contribute to social welfare. The existence and competitiveness of SMEs prove the entrepreneurial ability of economic actors in rural areas (Vijayanti \& Yasa, 2016). 
Other studies regarding the business feasibility of SMEs strengthen the result of this study. SME of Nata de Coco Aneka Sari found NPV of 119.2 million rupiahs, with payback periods of 2 years 9 months, and IRR of $71.2 \%$ (Wulandari \& Kusuma, 2012). The SME of green bean porridge stalls has a $12.2 \%$ IRR and a 6.15 month pay back period (Rinofah \& Kurniawan, 2016). Apple cider UMKM shows that the total cost for one production process is 5341 rupiahs, with profits reaching 26100 rupiahs (Hanani, Asmara, \& Hanafi, 2012).

The SMEs are important actors in a perfectly competitive market structure. Those who survive can pass natural selection, their business ventures are feasible and efficient. According to Vijayanti \& Yasa (2016), staple food traders compete with each other for consumers by providing the best service at competitive prices. They also sometimes lower prices below the average as a strategy to attract buyers.

\section{Research Implications}

This study has implications for policies regarding food supply and in particular the role of the government in protecting the provision of basic needs of its citizens. According to Menurut Siregar \& Ilham (2017), stabilization policy of upstream to downstream food needs requires legal certainty, in addition to regulating the business environment from conflicts among actors between large and small businesses.

1. Stability of domestic agricultural production. The government together with farmers and corporate businesses jointly plan and implement the achievement of domestic production stabilization, including mapping production areas, providing production facilities to distribution, and marketing agricultural and food products. Import policy is properly anticipated to meet domestic needs (Zakari et al., 2014).

2. Stabilizing food prices. Stable food prices support the planning of food needs, support the investment climate and food security. The food price also gives a return for sustainable business development (Helfert, 2001). The government should be able to anticipate price fluctuations due to climate change, changes in world prices, or other factors through various programs or incentives. This helps poor people to access their food needs.

3. Arrangement of space. Arrangement of production, distribution and marketing areas assist regional logistics planning. This helps the organization and mapping for supply and chain of food needs, as well as solutions to food problems up to the district level of the region (Siregar \& Ilham, 2017; Renting et al., 2003). Areas that are food insecure can be reached by distribution channels, while the government is present to give its role to help the food needs of the population.

4. Providing infrastructure. Road, sea and air infrastructure and supporting facilities can suppress obstacles while providing fast and efficient access to supply food chains (Barrett, 2008). Infrastructure reaches poor areas to export-import ports where food needs originate and destinate.

5. Ease of investment. The certainty of procedures, satisfied of service, policy transparency and the availability of capital, will shape the investment climate, including the development of SMEs in supporting food distribution. All people have the same opportunity, including cooperatives and SMEs, to invest, compete with each other positively, so that the allocation of food needs is efficient and affordable (Zakari et al., 2014).

\section{CONCLUSION AND SUGGESTION}

The investment in the business development of staple food stores in the rural area of Bojonegoro regency is feasible, based on the results of the calculation of NPV 35.6 million rupiahs, IRR $37.3 \%$, B/C Ratio 3.77, pay back period 1 year and 8 months.

The calculation of transaction trend of the food store from 2019 to 2023 shows an increase of the transactions average by 52.1 per year which is equal with the growth of $26.50 \%$.

Furthermore, investment calculation in term of sensitivity analysis of staple food business is feasible under the conditions of operational costs increase $2.0-4.0 \%$ and income decreases by 2.0 $4.0 \%$. 
This research has implications for food supply and distribution policies, including the stability of domestic food production, stabilization of food prices, regulation of space and area of production and distribution, infrastructure improvements for the smooth logistics and food distribution, and ease of investment.

\section{REFERENCES}

Badan Ketahanan Pangan. (2016). Butir Kegiatan Analis Ketahanan Pangan Bidang Distribusi Pangan. Disampaikan pada Bimtek Analisis Ketahanan Pangan, Bogor 26-28 September 2016.

Barrett, C. B. (2008). Smallholder market participation: Concepts and evidence from eastern and southern Africa. Food Policy, 33(4), 299-317.

https://doi.org/https://doi.org/10.1016/j.foodpo l.2007.10.005

George, J. M., \& Jones, G. R. (2005). Understanding and Managing Organizational Behavior (4th ed.). Cornell University: Pearson Prentice Hall. Retrieved from https://books.google.co.id/books?id=6zhEAAAA $\underline{Y A A]}$

Hanani, N., Asmara, R., \& Hanafi, A. A. (2012). Analisis Usaha dan Kelayakan Agroindustri Minuman Sari Buah Apel. Agricultural SocioEconomics Journal, 12(1), 1412-1425. Retrieved from http://agrise.ub.ac.id/index.php/agrise/article/vi ew/74/102

Helfert, E. A. (2001). Financial Analysis Tools and Techniques: A Guide for Managers. McGraw-Hill Education. Retrieved from https://books.google.co.id/books?id=Z34UBgAA QBAJ

Lantarsih, R., Widodo, S., Darwanto, D. H., Lestari, S. B., \& Paramita, S. (2017). Sistem Ketahanan Pangan Nasional: Kontribusi Ketersediaan dan Konsumsi Energi serta Optimalisasi Distribusi Beras. Analisis Kebijakan Pertanian, 9(1), 3351. https://doi.org/10.21082/akp.v9n1.2011.33$\underline{51}$
Renting, H., Marsden, T. K., \& Banks, J. (2003). Understanding alternative food networks: Exploring the role of short food supply chains in rural development. Environment and Planning A: Economy and Space, 35(3), 393-411. https://doi.org/10.1068/a3510

Rinofah, R., \& Kurniawan, S. (2016). Analisis Kelayakan Usaha Warung "Burjo" (Studi Kasus di Dusun Karang Gayam, Catur Tunggal, Depok Sleman, Yogyakarta). Kewirausahaan Dan Bisnis, 19(10), 1-11. Retrieved from https://jurnal.uns.ac.id/kewirausahaan-danbisnis/article/download/8324/7482

Siregar, M., \& Ilham, N. (2017). Upaya Peningkatan Efisiensi Usaha Ternak Ditinjau dari Aspek Agribisnis yang Berdaya Saing. Forum Penelitian Agro Ekonomi, 21(1), 57-66. https://doi.org/10.21082/fae.v21n1.2003.57-66

Soeharto, I. (2001). Manajemen Proyek (dari konsep sampai operasional): Menyiapkan perangkat, peserta, dan implementasi proyek (2nd ed.). Jakarta: Erlangga. Retrieved from http://onesearch.id/Record/IOS3985.libraC06011294\#toc

Vijayanti, M. D., \& Yasa, I. G. W. M. (2016). Pengaruh Lama Usaha dan Modal Terhadap Pendapatan dan Efisiensi Usaha Pedagang Sembako di Pasar Kumbasari. E-Journal Ekonomi Pembangunan, 5(12), 1347-1585. Retrieved from https://ojs.unud.ac.id/index.php/eep/article/vie $\mathrm{w} / 24794$

Wulandari, P. T., \& Kusuma, W. (2012). Analisis Kelayakan Finansial Pengembangan Usaha Kecil Menengah (UMKM) Nata de Coco di Sumedang, Jawa Barat. Jurnal Inovasi Dan Kewirausahaan, 1(2), 113-120. Retrieved from https://journal.uii.ac.id/ajie/article/view/2829

Zakari, S., Ying, L., \& Song, B. (2014). Market Integration and Spatial Price Transmission in Niger Grain Markets. African Development Review, 26(2), 264-273. https://doi.org/10.1111/1467-8268.12080 